\title{
THE EFFECTS OF MULTISENSORY APPROACH IN THE DEVELOPMENT OF THE READING COMPREHENSION SKILL
}

\author{
Lorena Parra G. \\ Associate Professor Universidad Técnica de Ambato, ECUADOR, Iparra@uta.edu.ec
}

\begin{abstract}
Learning is a process that directly involves the use of senses as the gate that leads to achieve the development of knowledge such as the acquisition of reading skills. The development of the reading skill in English as a Foreign Language (EFL) has been object of several studies through the use of different approaches. However, the improvement of reading comprehension using the multisensory approach has been given little attention by part of EFL researchers. Reading comprehension has been one of the most difficult reading subskills to develop in young learners in the teaching and learning process of EFL in the Ecuadorian context. The purpose of this study is to investigate the effect of applying the Multi-Sensory Approach in the development of the reading comprehension in English as a Foreign Language. The influence of Multisensory Approach on the reading skill development in young learners has contributed significantly in the learning process. Davies (2012) talks about the importance of multisensory activities as essential in the multisensory approach to develop the reading skill as it allows stimulating learning and teaching experiences for all learners who are still improving their reading skills. These learning activities provide different multisensory experiences. To achieve this objective, a pre/post-test experimental research design was applied in the conduction of this quantitative research study. A group of 24 university learners in the context of Ecuador participated in the experimentation. The results evidenced that the use of the multisensory approach has a positive influence in the development of reading comprehension, contributing to the success of the EFL programme.
\end{abstract}

Keywords: multisensory approach, reading comprehension, EFL learning process.

\section{INTRODUCTION}

Walet (2011) expresses that visual, auditory, kinesthetic and tactile are the main senses involved directly when using the multisensory approach to develop multisensory activities. Also, these senses help discover the different learning styles which provide multiple pathways for teaching and learning. Learners who struggle with the development of the reading skill need to be associated with creative learning activities to help overcome learners' learning difficulties. In several studies, it has been proved that the Multisensory Approach or also known as VAKT method which consists on using visual, auditory, kinesthetic and tactile senses had helped to develop cognitive program instruction.

The present study aimed to examine the EFL undergraduate students' progress on their reading comprehension and its effects of using the multisensory approach in the EFL learning process. To achieve this aim, the students participated in an experimental research. In view of the study purpose, the following research question and hypothesis were posed:

Question: Does the multisensory approach have any significant effect on improving the learners reading 
comprehension skill?

Hypothesis: The multisensory approach does not have any significant effect on improving the learners learning comprehension skill.

\section{LITERATURE REVIEW}

\subsection{Reading Comprehension Skill}

Reading is considered as a multisensory activity, which involves cognitive, perceptual and motor interactions with the text or book that is being read (Mangen, 2010). The purpose of this skill is to understand and analyse information from a written text in order to interpret what the author wants to say or transmit. Reading is known as a complex, interactive and comprehending skill that needs time and materials to develop it successfully. There are three types of reading. (1) Reading for pleasure allows practicing this skill in order of being a good reader. (2) Reading for information increase the background knowledge of the reader. (3) Reading for research is focused on reading scientific information to design investigative works or any study. (Bojovic, 2014). Regardless of the type of reading, English learners have difficulties in learning successfully this skill because of its complexity, interference of the mother tongue, complex vocabulary or grammar, and the use of inadequate teaching/ learning methods (Altmisdort, 2016). However, reading difficulties are not impossible to solve. It is difficult to read something that is not in the mother tongue, but the use of good activities will have a positive influence on the reading skill improvement. For that reason, in a classroom, teachers need to consider as a solution the use of multisensory activities as part of the multisensory approach since they help to decrease reading difficulties (Gerlach, 2017).

Reading comprehension is required in all school levels since it is considered as a tool for students' knowledge development that allows them to approach to the culture and learning in different areas. Having a good reading comprehension skill is a guarantee to develop other knowledge skills. Comprehension helps to solve different kinds of reading issues, to interpret and analyse graphics, data, maps, or other reading tasks.

Kuşdemir \& Bulut (2018) point out that reading and comprehension are combining for a better learning process as the ultimate objective of reading is comprehension. Reading comprehension is a process that is carried out by the reader and the text in an interactive way. Comprehension is considered as a process in which the reader uses their own knowledge or their previous learning experience to deduce or infer the content of the text. Comprehension is also known as a complex skill that involves conscious and unconscious learning/ teaching strategies. Comprehension entails the application of reasoning strategies to construct a meaning model based on the main ideas of the text. Moreover, Özdemir \& Akyol (2019) talk about the importance of reading comprehension as a competence that influence on the development of the reading skill in general, which is very useful in lifelong learning. To develop a good comprehension skill in reading is essential to participate in the readers' communities of the school, everyday life, or even for personal enjoyment.

In addition, from the cognitive point of view of Brand \& Dalton (2012) comprehension is a competence that allows improving learners' capacities and functions to process information. A developed imagination and a proper understanding allows learners to choice the information, examine it, summarize it, organize it, distinguish the main ideas from the secondary ones, keep it in the long-term memory in the form of main thoughts which will help remember, because its storage has been produced with a great understanding and significance. In the comprehensive reading development, there are some difficulties in the learning process, caused by different causes that make the reader avoid reading. To prevent these difficulties, the teacher plays an important role. Nation (2019) also talks about the idea of reading comprehension difficulties. For English learners, comprehend a text with vocabulary that they do not know is one of the most difficult things, especially if the teacher uses traditional methods that lead to get bored students. Pourhosein Gilakjani \& Sabouri (2016) suggest that the best strategy for developing the reading comprehension in order to improve in general the reading skill, it is the use of innovative learning activities. Furthermore, Mireles (2018) expresses that reading comprehension and multisensory activities have a positive relationship in order to get the expected learning outcomes. The use of the senses in a reading class has a great impact, especially at the moment to comprehend the information (Cho et al., 2019).

\subsection{Multisensory Approach}

Multisensory approach has been used in different disciplines to encourage positive attitude, and easier and fun learning. This approach combines different activities that involve two or three types of senses in order to gain knowledge (Rains, Kelly \& Durham 2008 as cited in Yurniwati, 2018). Multisensory approach usually uses visual, auditory, and kinaesthetic elements simultaneously to achieve optimal learning process which 
also helps to strengthen learners' memory and their motivation serving this as a path of information to the brain (Spence \& Endler, 2013). The quality of learning is significantly influenced when learners and various concrete objects involve sensory devices combining the physical learning environment and the interaction process. According to Baines (2008), the human brain becomes active and develops if the person speaks, hears, moves and thinks motivating an optimal learning in a multisensory environment (cited in Gerlach, 2017). The variety of learning tools that integrate various senses gives more positive impact to the learner and leads to create a learning environment with more options for students to find concepts through discovery and exploration (Skoglund et al., 2020).

Multisensory integration can be clearly beneficial to produce response enhancement when the signal of a single modality is weak or when a sensory system is deprived of its modality specific brain area (Làdavas, 2008). In other words, the activation of multisensory systems in response to stimulus may represent the neural correlate of sensory compensation after damage to one sensory system. For this reason, learning in a "unisensory" environment may be less efficient, natural and incapable of creating an optimal climate for acquiring knowledge. For creating a multisensory learning environment, it is necessary to involve learners in a variety of activities that motivate them to be connected in the development of the learning process through the integration of the different senses.

It is important to have new ways of learning in order to reinforce students' knowledge (Fernández et al., 2019). For this reason, an innovative way that helps learners to acquire knowledge in a better way is multisensory activities (Kivilehto et al., 2015). In addition to this, Maliki \& Yasin (2017) explain that multisensory activities are the best learning and teaching way in which all the senses have the purpose to facilitate knowledge acquisition. Furthermore, Nasir (2014) adds that multisensory activities have a great influence to increase the reading ability which is the principal skill that needs to be achieved for knowledge acquisition.

Besides, Hoisington (2015) mentions that multisensory activities are different ways of teaching, in which more than one sense is involved at the moment to develop an activity. The different parts of the brain are activated simultaneously when the individuals use their senses for knowledge acquisition. The main senses using in the multisensory activities are visual, kinaesthetic, auditory, and tactile. Moreover, Syalviana (2019) explains that multisensory activities are the best way to improve the reading skills, (Nurjanah \& Eka, 2017) especially for learners who have reading difficulties, or (Budiman, 2017) that do not have the interest to read.

\section{METHOD}

This study involves quantitative research as data collection procedures resulted in numerical data that was analysed by statistical methods. According to Apuke (2017) the aim of a quantitative method is to quantify, define and analyse variables to obtain results. It also uses and analyses the numerical data using statistical techniques to answer specific questions like how, how much or many, what, where, when, and who. It describes the methods to explain a phenomenon through gathering information in numerical form. Based on this criteria, this research used an experimental design considering subjects were assigned randomly. A pretest and post-test were applied to verify the efficacy of the experiment. The manipulation of the independent variable determines the effect on the dependent variable (Mackey \& Gass, 2015). The experimental group were exposed to the use of multisensory activities to perform their reading skills specifically the reading comprehension subskills in class hours and in outside classroom activities during the semester of studies. The learners' reading comprehension improvement in the post test was compared to identify whether there were differences after applying the experiment.

\subsection{Participants}

This study was conducted with 24 Ecuadorian EFL university learners. The researcher attempted to have the same number of female and male participants (12 males and 12 females). The population belonged to an English Teacher Program in which as part of the curriculum they have to success in academic reading. The ages of the students ranged between 18 to 21 years old. Their English language proficiency level is A2 reason for which the KET test was used to measure their language improvement related to reading comprehension.

\subsection{Instruments}

The Key English Test (KET) from Cambridge University was applied in two different versions. One version was applied for the pre-test and the other one for the post-test.

Both tests comprehend of eight parts: 1: Matching, 2: Gapped sentences, 3: Multiple choice questions based 
on conversation, 4: Factual text matching, 5: Text with gaps or multiple choice cloze, 6: Word completion, 7: Text with gaps or open cloze, 8: Fill in a form or information transfer (see fig.2). Second, a reading comprehension rubric was used to analyse, interpret, and evaluate the language proficiency level of students. The rubric comprehends of seven components which were improved by using the multisensory activities: 1: Monitoring, 2: Prior knowledge, 3: Visualizing, 4: Paraphrasing, 5: Synthesizing, 6: Focus on context, 7: Inferring (see fig. 3). Third, different multisensory activities were applied to develop the different components of the rubric which are based on the multisensory approach. Those activities were focused on the main senses: Visual, auditory, kinesthetic, and tactile.

\subsection{Data collection procedure}

In the present research, the process of the information was carried out following four steps in order to achieve the research objectives. First, a Pre-test for the whole population (experimental group) was applied to know the level of the students in relation to reading specifically reading comprehension. For this purpose, the reading section of the KET test was used. The data collection was tabulated to obtain the different results that allowed to determine the level of the students' reading knowledge based on the rubric. Second, the application of the multisensory activities was carried out in 40 minutes of each English class. Third, after the application process, using another reading section of the KET Test (post-test), the whole population was evaluated again in order to show their reading skill improvement and the effectiveness of the multisensory activities. Finally, the data collection was tabulated to obtain the different results. The pre-test and post- test helped to determine if the level of the students' reading knowledge improved.

\subsection{Data Analysis}

This study used quantitative method. In order to know if there is a significant effect on applying the multisensory approach to develop the reading comprehension skill of the learners, the pre- test and post-test results were compared by using statistical analysis as described in the next section.

\section{RESULTS}

This study investigated the influence of multisensory approach on the reading comprehension skill development. To answer the research question, first the normal distribution of data was checked by using the Shapiro Wilk test as in table 1.

Table 1. Normal distribution of the scores of the reading comprehension test

\begin{tabular}{|l|l|l|l|l|l|l|l|}
\hline & $\Sigma$ & Median & Variance & SS & b & SD & p-value \\
\hline Pre-test & 421 & 17,54 & 10,61 & 202,23 & 18,20 & 3,2568 & 0,884 \\
\hline Post-test & 945 & 39,38 & 10,42 & 165,23 & 17,29 & 3,2227 & 0,884 \\
\hline
\end{tabular}

The collected data of the pre and post-test were compared through a deep analysis by using the Wilcoxon Rank test as in table 2. Table 2 indicates that there are a total of 24 collected ranges or results of both tests which are analyzed in the next way. There are 24 positive ranges, 0 negative ranges, and 0 similar ranges which means that all the scores of the post-test are higher than the pre-test. To sum up, the multisensory activities used in the experimentation as part of the multisensory approach helped to achieve better results in students' reading knowledge.

Table 2: Pre and post-test results

\begin{tabular}{|l|l|l|l|l|}
\hline & Ranges & N & Average range & Sum of ranges \\
\hline & Negative ranges & $0 \mathrm{a}$ &, 00 &, 00 \\
\hline Post-test & Positive ranges & $24 \mathrm{~b}$ & 12,5 & 300 \\
\hline Pre-test & Drwas & $0 \mathrm{c}$ & & \\
\hline & Total & 24 & & \\
\hline
\end{tabular}


In table 3, Wilcoxon rank test shows that when $Z$ is obtained with a significance of 1,74 (bilateral) and the value of $p$ is 0.0409 , and this $p$-value is less than 0.05 , showing that the application of multisensory approach had a positive influence on the development of the reading comprehension of the students who participated in the experiment.

Table 3. Wilcoxon Test Statistics of contrast.

\begin{tabular}{|l|c|}
\hline & Post-test Pre-test \\
\hline$Z$ & 1,74 \\
\hline Sig. asintót. (bilateral) & 0,0409 \\
\hline
\end{tabular}

In addition, different comparative figures based on the results obtained in the pre-test and post-test are shown which disclose the results achieved.

Fig. 1 illustrates individual results of the 24 students based on three aspects: pre-test (blue bars), post-test (orange bars), and the average score (grey bars). In the pre-test, the whole population obtained a score from 12 to 24 out of 55 which indicates a low level of the reading domain. However, in the post-test, students were able to obtain scores from 35 to 48 points which show a better reading domain. Contrasting the scores of both tests, there is a remarkable difference that most of the students improve their reading skill after the application of the multisensory activities.

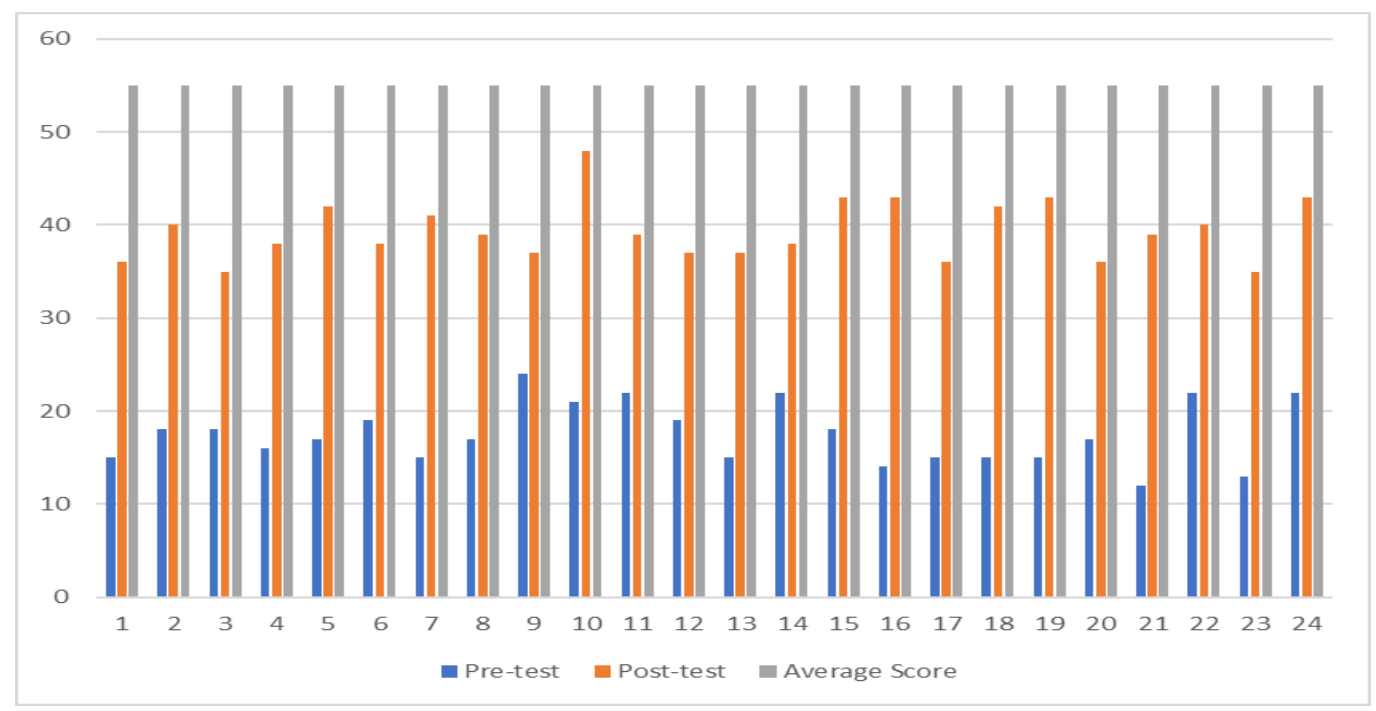

Fig. 1. Pre and post-test individual comparison scores

Fig. 2 displays a comparison based on the general scores of the 24 students that were obtained in each part of the pre and post-test. It is important to take into account that in each part of the reading sample of the KET test, there are specific activities to do described below.

The first section represented by bar 1 corresponds to matching activities, the second one represents gapped sentences, the third bar is related to conversation activities, and the seventh one corresponds to completion text with gaps. The sections clearly show that in the pre and post-test the general scores has a noticeable difference, the students improved the reading skill significantly. The fourth section has factual text activities; the fifth part of the test is related to text gap activities while the sixth one demands word completion. The eight section of the test has filling activities. Even though the students already had a regular command of these activities, it is also shown that they obtained better scores after the application of the multisensory approach.

Finally, it is necessary to emphasize that in the third section of the test that has activities based on conversations the comparison of the general scores shows the best result of achievement than the other sections. 


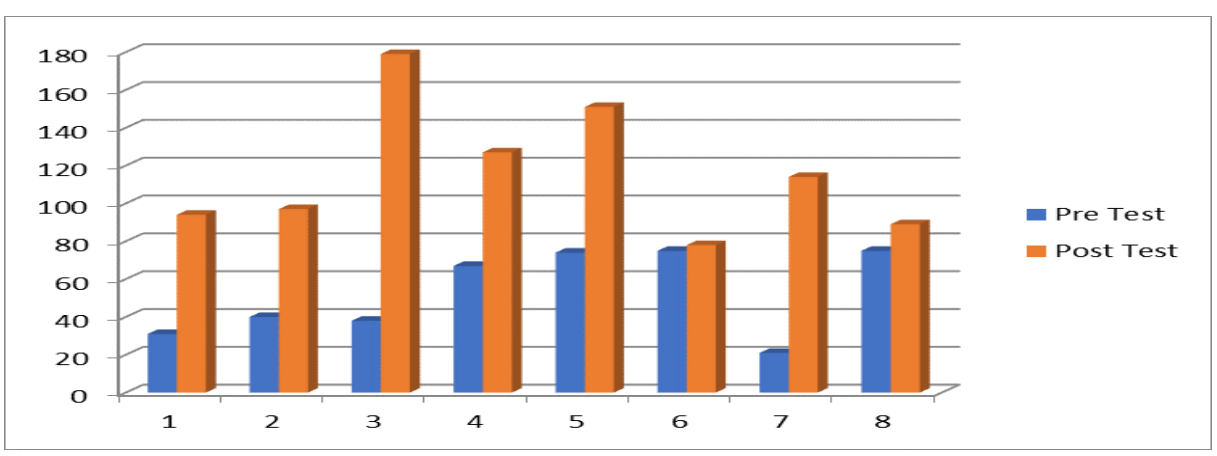

Figure 2. Pre and post-test general comparison scores

Fig. 3 shows the eight components of the rubric that were taken into account to evaluate the students' reading comprehension level through the development of the 8 parts of the reading sample of the KET test.

In the questioning, visualizing, and paraphrasing components of the rubric, it is observable that the students improved after the application of the experiment becoming a regular achievement. In the components of monitoring comprehension, prior knowledge and inferring students had a significant improvement after the application, they increase two levels which is a good achievement. However, in the component of synthesizing the students maintain their level which was not the expected result.

Besides, the prior knowledge component has more acceptance by the students since they developed until level 4 which means $100 \%$. This result may be the product of the application of multisensory activities as part of the multisensory approach.

To sum up, students can improve most of the comprehension components which help them to acquire and achieve the reading skill in a better way.

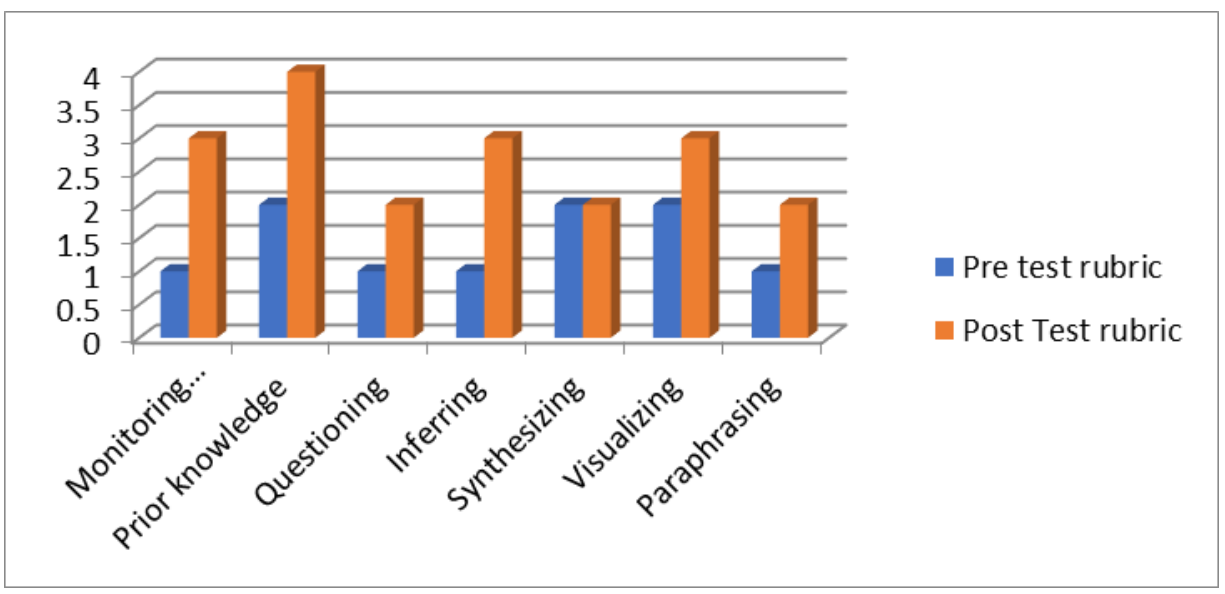

Fig. 3. Pre and post-test rubric comparison

\section{CONCLUSION}

This investigative work studied the students' improvement of the reading comprehension skill by using multisensory approach as an effective and motivating way to learn. Besides, to determine if the multisensory approach had an influence in the reading process a pre-test and post-test was taken to know the results that were reached. An experimental group of 24 students were part of the study who help to get the follow major results.

Firstly, a quantitative method was applied for gathering information, as well as, a pre-experimental study method in which a pre-test and post-test were developed in just one group called experimental group. To identify the different results between the pre- test and post-test scores, different comparative figures were displayed and the Wilcoxon rank test was applied. Finally, the results showed that the multisensory approach had a great effect on the young students' learning because the use of the multisensory approach helped recognize and remember letters, words, and phrases which are the main steps to develop reading skill in a good way. (Moustafa \& Ghani, 2016)

Secondly, the results obtained in the pre-test were analysed and it was determined that despite the fact 
students study English Reading as one of the mandatory subjects in the English as a Foreign Language Programme, there is a low reading comprehension level which may be the main reason for the low grades obtained by the learners in the pre-test. Students did not complete all the questions of the pre-test because they did not comprehend well what they read, they may have felt selflessness and frustration leaving many questions in blank. However, after the application of multisensory activities based on VAKT senses as the main strategy of the multisensory approach, the post-test was carried out, also the results were analysed and it was determined that they understood better what they read demonstrating more motivation and less frustration and selflessness. The results showed the improvement of a reading comprehension domain as they completed most of the questions without fear, resulting in better scores. Moreover, the application of the Wilcoxon rank test allowed to determine the influence that multisensory activities have when developing the reading comprehension skill, taking into account the collected results in the pre and post-test. Moreover, the statistical results showed that after using multisensory activities most of the young learners got positive results because learning through Multisensory Language Teaching made the reading activities more memorable and enjoyable learning experience, but, above all, it helped keep the information in learners' long-term memory. (Celik Korkmaz \& Karatepe, 2018)

Thirdly, the result obtained showed that multisensory activities are considered as a helpful method for developing in a good way the reading skill. For learners who have difficulties in the learning process, especially, problems in the reading skills improvement, the activities that involve the use of senses are very useful for solving any reading problem because it uses all the pathways in the brain in order to enhance memory, abilities, and learning process. (Jeyasekaran, 2015)

Finally, it is important to point out that the use of the senses is a useful, productive and a motivating way to learn a foreign language as all learners are involved in the teaching and learning process through diverse activities that catch the attention of the different learning styles when using a diversity of tasks related to multisensory tasks. Multisensory approach helps develop the different skills, especially the complex ones like the reading skill since the exposure of the body and the surroundings is the best learning stimulus. A learning activity has high quality and impact when the senses are used for learning as the information will retain in our long- term memory. (Baker \& Adams, 2015).

\section{REFERENCE LIST}

Altmisdort, G. (2016). The Effects of L2 Reading Skills on L1 Reading Skills through Transfer. English Language Teaching, 9(9), 28. https://doi.org/10.5539/elt.v9n9p28

Apuke, O. D. (2017). Quantitative Research Methods: A Synopsis Approach. Kuwait Chapter of Arabian Journal of Business and Management Review, 6(11), 40-47. https://doi.org/10.12816/0040336

Baker, L., \& Adams, A. (2015). Picture Worth ? Integrating Visual Literacy in Language Learning with Photographs. English Teaching Forum, Brumberger.

Bojovic, M. (2014). Reading Skills and Reading Comprehension in English for Specific Purposes. The International Language Conference on the Importance of Learning Professional Foreign Languages for Communication between Cultures., 1, 1-5.

Brand, S. T., \& Dalton, E. (2012). Universal Design for Learning: Cognitive Theory into Practice for Facilitating Comprehension in Early Literacy. Forum on Public Policy Online, 2012(1), 1-19.

Budiman, I. (2017). The Influence of Teaching Reading Using Multisensory Method on Students' Reading Skill: A Quasi-Experiment at the' Second Grade of SMP Annaja Cipeundeuy. UIN Sunan Gunung Djati Bandung.

Celik Korkmaz, S., \& Karatepe, C. (2018). The Impact of Multi-Sensory Language Teaching on Young English Learners' Achievement in Reading Skills. Novitas-ROYAL (ResCelik Korkmaz, S., \& Karatepe, C. (2018). The Impact of Multi-Sensory Language Teaching on Young English Learners' Achievement in Reading Skills. Novitas-ROYAL (Research on Youth and Language), 12(2), 80-95. Earch on Youth and Language), 12(2), 80-95.

Cho, E., Capin, P., Roberts, G., Roberts, G. J., \& Vaughn, S. (2019). Examining Sources and Mechanisms of Reading Comprehension Difficulties: Comparing English Learners and Non-English Learners Within the Simple View of Reading. Journal of Educational Psychology, 111(6), 982-1000. 
https://doi.org/10.1037/edu0000332

Davies, C. (2012). Creating multisensory environments : practical ideas for teaching and learning. Routledge.

Fernández, G. A., Ocampo, R. A., Costantino, A. R., \& Dop, N. S. (2019). Application of Didactic Strategies as Multisensory Teaching Tools in Organic Chemistry Practices for Students with Visual Disabilities. Journal of Chemical Education, 96(4), 691-696. https://doi.org/10.1021/acs.jchemed.8b00816

Gerlach, D. (2017). Reading and spelling difficulties in the ELT classroom. ELT Journal, 71(3), 295-304. https://doi.org/10.1093/elt/ccw088

Hoisington, B. (2015). Multisensory Activities to Teach Reading Skills. Minnesota Literacy Council, 1-24. https://doi.org/10.1016/j.theriogenology.2015.11.028

Jeyasekaran, J. M. (2015). Effectiveness of visual auditory kinesthetic tactile technique on reading level among dyslexic children at Helikx Open School and Learning Centre, Salem. International Journal of Medical Science and Public Health /, |, 315-318. https://doi.org/10.5455/ijmsph.2015.0511201467

Kivilehto, S., Malin, A., \& Räty, M. (2015). WHAT IS A MULTISENSORY TENT? DEVELOPING A MULTISENSORY METHOD AND NEW LEARNING ENVIRONMENTS.

Kuşdemir, Y., \& Bulut, P. (2018). The Relationship between Elementary School Students' Reading Comprehension and Reading Motivation. Journal of Education and Training Studies, 6(12), 97. https://doi.org/10.11114/jets.v6i12.3595

Làdavas, E. (2008). Multisensory-based Approach to the Recovery of Unisensory Deficit. Annals of the New York Academy of Sciences, 1124(1), 98-110. https://doi.org/10.1196/annals.1440.008

Mackey, A., \& Gass, S. M. (2015). Second language research: Methodology and design. Routledge.

Maliki, N. S. B. M., \& Yasin, M. H. M. (2017). Application of Multisensory in Learning Alphabets Identification Skills for Special Education Students. Journal of ICSAR, 1(2), 150-154. https://doi.org/10.17977/um005v1i22017p150

Mangen, A. (2010). Hypertext fiction reading: Haptics and immersion. Journal of Research in Reading, 31(4), 404-419. https://doi.org/10.1111/j.1467-9817.2008.00380.x

Mireles, D. (2018). A Single Case Research Design Using Orton-Gillingham Based Reading Instruction. ProQuest LLC, Ed.D., 141.

Moustafa, A., \& Ghani, M. Z. (2016). The Effectiveness of a Multi Sensory Approach in Improving LetterSound Correspondence among Mild Intellectual Disabled Students in State of Kuwait. Journal of Education and Practice, 7(32), 151-156.

Nasir, N. (2014). PENGARUH METODE SENSORI DALAM MENINGKATKAN KEMAMPUAN MEMBACA PERMULAAN. TERAMPIL: Jurnal Pendidikan Dan Pembelajaran Dasar, 1(1), 37-41. https://doi.org/10.24042/TERAMPIL.V111.1303

Nation, K. (2019). Children's reading difficulties, language, and reflections on the simple view of reading. Australian Journal of Learning Difficulties, 24(1), 47-73. https://doi.org/10.1080/19404158.2019.1609272

Nurjanah, \& Eka. (2017). Metode Multisensori Terhadap Kemampuan Mengenal Lambang Bilangan 1-10 Pada Anak Autis. Jurnal Pendidikan Khusus, 9(2).

Özdemir, E. Ç., \& Akyol, H. (2019). The development of a reading comprehension. Universal Journal of Educational Research, 7(2), 563-570. https://doi.org/10.13189/ujer.2019.070229

Pourhosein Gilakjani, A., \& Sabouri, N. B. (2016). How Can Students Improve Their Reading Comprehension Skill? Journal of Studies in Education, 6(2), 229-240. https://doi.org/10.5296/jse.v6i2.9201

Skoglund, P., Persson, T., \& Rédei, A. C. (2020). A Multisensory Approach to Rock Art: Exploring Tactile and Visual Dimensions in the Southern Scandinavian Rock Art Tradition. Proceedings of the Prehistoric Society, 1, 1-16. https://doi.org/10.1017/ppr.2020.1

Spence, C., \& Endler, J. A. (2013). Review: The New Handbook of Multisensory Processing: Sensory Ecology, Behaviour, and Evolution. Perception, 42(5), 586-590. https://doi.org/10.1068/p4205rvw 
Syalviana, E. (2019). Metode Multisensori Sebagai Penanganan Kesulitan Membaca Siswa Retardasi Mental. Al-MAIYYAH : Media Transformasi Gender Dalam Paradigma Sosial Keagamaan, 12(1), 301320. https://doi.org/10.35905/almaiyyah.v11i2.660

Walet, J. (2011). Differentiating for Struggling Readers and Writers: Improving Motivation and Metacognition through Multisensory Methods \& Explicit Strategy Instruction. Journal of the American Academy of Special Education Professionals, 83-91.

Yurniwati, Y. (2018). Improving the Conceptual and Procedural Knowledge of Prospective Teachers through Multisensory Approach: Experience from Indonesia. JRAMathEdu (Journal of Research and Advances in Mathematics Education), 3(2), 106. https://doi.org/10.23917/jramathedu.v3i2.6374 